\title{
Enhancement of sensitivity of the haemagglutination test for echinococcosis by use of Staphylococcus aureus protein A
}

\author{
S. C. PARIJA and R. SAMBASIVA RAO \\ Department of Microbiology, Jawaharlal Institute of Postgraduate Medical Education and Research, \\ Pondicherry-605 006, India
}

\begin{abstract}
Summary. A modification of the indirect haemagglutination test is described for the serodiagnosis of echinococcosis. In the modified test the Cowan I strain of Staphylococcus aureus, which contains protein A, was used to enhance haemagglutination of sensitised red cells. The test was performed in parallel with the indirect haemagglutination test on 31 sera from surgically-confirmed cases of hydatid disease and on 45 sera from healthy blood donors. Use of $S$. aureus protein A enhanced the sensitivity of the test and greatly increased the titres obtained with most of the sera. None of the sera from healthy blood donors exhibited a titre $>64$, whereas all but two of the sera from cases of hydatid disease exhibited titres $>128$. The immunoassay is simple, inexpensive and requires little technical skill. It has the potential for wide application in the serodiagnosis of echinococcosis.
\end{abstract}

\section{Introduction}

The need for an immunodiagnostic test for echinococcosis which is simple, rapid and yet sensitive in laboratory and field conditions has resulted in the development of various tests, which include: double diffusion (Ouchterlony, 1958), immunoelectrophoresis (Ardehali et al., 1977), countercurrent immunoelectrophoresis (Kelkar and Kotwal, 1975), cellulose acetate membrane counter-immunoelectrophoresis (Mansueto et al., 1980), complement fixation (Varela-Díaz and Coltori, 1974), latex agglutination (Chemtai et al., 1981), indirect haemagglutination (IHA) (Iacona et al., 1980), enzyme linked immunosorbent assay (ELISA) (Iacona et al., 1980) and dot-ELISA on nitrocellulose paper (Schantz et al., 1984). However no single test provides complete sensitivity and specificity for echinococcosis and a combination of two or three methods may be necessary to obtain reliable results (Chemtai et al., 1981).

Because the IHA test is inexpensive, easy to perform and can be read without errors of subjectivity, it is potentially useful in the diagnosis of echinococcosis (Lewis et al., 1975; Parija et al., 1983). However, the IHA test is not as sensitive as ELISA although use of double-aldehyde stabilised cells enhances its sensitivity (Parija and Ananthakrishnan, 1985).

Received 29 Nov. 1985; accepted 19 Feb. 1986
We describe here the use of Staphylococcus aureus protein A to further enhance the sensitivity of the IHA test in the serodiagnosis of echinococcosis.

\section{Materials and methods}

\section{Antigen}

Hydatid cyst fluid antigen was obtained from patients at surgical operation and processed by the method described by Arabatzis and Papapanagiotou (1963).

\section{Sera}

A total of 31 sera from surgically-confirmed cases of hydatid disease and 45 sera from healthy blood donors was collected. All were stored at $-20^{\circ} \mathrm{C}$.

\section{Bacteria}

Two strains of S. aureus were used: Cowan I, which possesses protein A and Wood 46, which lacks protein A. The strains were grown on Mueller Hinton Agar at $37^{\circ} \mathrm{C}$ and stabilised with formalin and heat as described by Camargo et al. (1983). After incubation for $24 \mathrm{~h}$ cultures were harvested at $3000 \mathrm{~g}$ for $10 \mathrm{~min}$ and washed three times in phosphate-buffered saline (PBS) $(p \mathrm{H} \mathrm{7.2)} \mathrm{con-}$ taining sodium azide $0.05 \% \mathrm{w} / \mathrm{v}$. The pellet was fixed in 10 volumes of formaldehyde $1.5 \%$ in PBS at room temperature for $90 \mathrm{~min}$, washed twice in PBS, resuspended in 10 volumes of PBS-azide and heated for $5 \mathrm{~min}$ at $80^{\circ} \mathrm{C}$. The bacteria were again harvested and washed twice; a $10 \%$ 
suspension of cells in PBS with sodium azide $0.1 \%$ was then prepared and stored in small volumes at $4^{\circ} \mathrm{C}$. Before use, stored suspensions were diluted to the desired concentration in $p \mathrm{H} 7.6$ buffer $(100 \mathrm{~mm} \mathrm{NaCl}, 50 \mathrm{~mm}$ EDTA, $50 \mathrm{~mm}$ Tris $\mathrm{HCl}$ ) containing bovine serum albumin $4 \mathrm{mg} / \mathrm{ml}$ of buffer.

Preparation and sensitisation of double-aldehyde stabilised ( $D A S$ ) cells

Human group $\mathrm{O}$ red blood cells were stabilised with pyruvic äldehyde, tannic acid and glutaraldehyde as described by Parija and Ananthakrishnan (1985). The DAS cells were sensitised with the hydatid antigen as described by Farshy and Kagan (1972). DAS red cells were washed twice with PBS. Packed cells were suspended in 10 volumes of various concentrations of antigen in PBS ( $p \mathrm{H} \mathrm{6.4)} \mathrm{and} \mathrm{incubated} \mathrm{at} 50^{\circ} \mathrm{C}$ for $5 \mathrm{~min}$. The suspension was then kept overnight at $4^{\circ} \mathrm{C}$ before re-incubation at $50 \mathrm{C}$ for $5 \mathrm{~min}$. The sensitised red cells were washed twice with PBS and then with PBS containing bovine serum albumin (BSA) $0.1 \%$. Finally, a suspension of sensitised cells $(1 \%)$ was prepared in PBS containing BSA. The optimum sensitising dose of the antigen (the lowest amount of the antigen showing the maximum haemagglutination titre) was determined for each batch of the antigen by chessboard titration against known positive and negative sera.

\section{Indirect haemagglutination (IHA) test}

A $25-\mu 1$ volume of PBS containing BSA $0.1 \%$ was dispensed in each well of a U-bottomed microtitration tray. A $25-\mu$ l volume of serum was added to the first well of the appropriate row. The sera were then serially diluted up to the eleventh well, leaving the last well as a serumfree control. A $25-\mu$ l volume of DAS cells, sensitised with the optimum sensitising dose of antigen, was added to each well. The plate was gently agitated for $2 \mathrm{~min}$ and incubated at room temperature for $\mathrm{lh}$, followed by overnight incubation at $4 \mathrm{C}$. Controls consisting of known positive and unsensitised DAS cells were included with each test. The IHA pattern was recorded as described by Stavitsky (1954).

\section{Protein A-antibody mediated haemagglutination}

The method was similar to IHA except that a suspension of $S$. aureus Cowan I strain, prepared as described above, was added to the diluted sera before addition of sensitised cells. The optimal concentration of $S$. aureus cells was determined by chessboard titration with various suspensions of bacteria $(0 \cdot 1,0 \cdot 2,0 \cdot 3,0 \cdot 4$ and $0.5 \%)$ and known positive and negative sera. The lowest concentration of bacterial cells which showed the maximum haemagglutination was considered to be the optimum concentration of $S$. aureus valid for that batch of the cells.

A $25-\mu 1$ volume of PBS containing BSA was dispensed in all the rows of a U-bottomed microtitration plate. A $25-\mu$ volume of serum was added to the first well of each row. The sera were then serially diluted in twofold steps up to the tenth wells. A $25-\mu 1$ volume of $S$. aureus suspension at the optimal concentration $(0.2 \%)$ was dispensed into each well. The plates were then agitated at 70 oscillations/ $\mathrm{min}$ for $30 \mathrm{~min}$ at room temperature. A 25 $\mu \mathrm{l}$ volume of sensitised DAS cells was then added to each well. The plates were gently agitated for $2 \mathrm{~min}$ and incubated at room temperature for $1 \mathrm{~h}$, followed by overnight incubation at $4^{\circ} \mathrm{C}$. The co-haemagglutination patterns obtained were scored as for the IHA test by the method of Stavitsky (1954).

Appropriate controls were included in each test. As a control of the effect of $S$. aureus protein A, tests were repeated with the Wood 46 strain of $S$. aureus which lacks protein $A$.

\section{Results}

The results of the IHA test were compared with those of the protein A-modified assay for sera from 31 patients with surgically-confirmed echinococcosis. Titres $\geqslant 128$ were obtained with 25 of $31(80.6 \%)$ sera tested by the IHA method and 29 of $31(93.5 \%)$ sera tested with the protein A-modified assay (table). All titres obtained in the presence of $S$. aureus protein $\mathrm{A}$ were at least double those observed by IHA; in most cases, much greater increases in titre were obtained and in one case a titre of 128 by IHA was 262144 in the protein Amodified assay.

Serum-free controls revealed no haemagglutination by the $S$. aureus suspensions alone. In tests with the Wood 46 strain of $S$. aureus instead of the Cowan I strain, titres were identical to those of the unmodified IHA test. None of 45 sera from healthy blood donors exhibited a titre $>64$ when tested by the protein A method.

\section{Discussion}

The Cowan I strain of $S$. aureus bearing protein A specifically binds IgG without affecting its immunological activity (Langone, 1982). This property of protein $A$ is employed in several diagnostic tests for the demonstration of antibodies (Bergquist and Waller, 1983; Camargo et al., 1983) and antigens (Kronvall, 1973; Sivadasan et al., 1984).

The IHA test used for the serodiagnosis of echinococcosis is simple, specific and moderately sensitive (Iacona et al., 1980, Chemtai et al., 1981; Parija and Ananthakrishnan, 1985). However it is not as sensitive as ELISA or radio-immunoassay because some of the IgG bound to red cells fails to cross link the cells so that haemagglutination does not occur. Cross-linking could be achieved by use of 
Table. Comparison of antibody titres obtained by two tests on 31 sera from patients with echinococcosis.

\begin{tabular}{|c|c|c|}
\hline \multirow[b]{2}{*}{ Serum no. } & \multicolumn{2}{|c|}{ Antibody titres } \\
\hline & IHA test & SAPA-IHA test \\
\hline H19 & 512 & 16384 \\
\hline $\mathrm{H} 20$ & 1024 & 65536 \\
\hline $\mathrm{H} 21$ & 256 & 512 \\
\hline $\mathrm{H} 22$ & 128 & 2048 \\
\hline $\mathrm{H} 23$ & 256 & 2048 \\
\hline $\mathrm{H} 24$ & 128 & 16384 \\
\hline $\mathrm{H} 25$ & 4 & 32 \\
\hline $\mathrm{H} 26$ & 128 & 512 \\
\hline $\mathrm{H} 27$ & 1024 & 32768 \\
\hline $\mathrm{H} 28$ & 256 & 4096 \\
\hline $\mathrm{H} 29$ & 4 & 512 \\
\hline $\mathrm{H} 30$ & 256 & 1024 \\
\hline $\mathrm{H} 31$ & 512 & 1024 \\
\hline H32 & 256 & 131072 \\
\hline H33 & 128 & 2048 \\
\hline H34 & 256 & 512 \\
\hline H35 & 2 & 64 \\
\hline H36 & 512 & 16384 \\
\hline $\mathrm{H} 37$ & 4 & 256 \\
\hline H38 & 256 & 512 \\
\hline H39 & 512 & 32768 \\
\hline $\mathrm{H} 40$ & 128 & 8192 \\
\hline $\mathrm{H} 41$ & 1024 & 131072 \\
\hline $\mathrm{H} 42$ & 16 & 256 \\
\hline $\mathrm{H} 43$ & 128 & 262144 \\
\hline H44 & 128 & 256 \\
\hline H45 & 256 & 8192 \\
\hline $\mathrm{H} 46$ & 128 & 4096 \\
\hline $\mathrm{H} 47$ & 128 & 2048 \\
\hline $\mathrm{H} 48$ & 128 & 512 \\
\hline $\mathrm{H} 49$ & 16 & 256 \\
\hline
\end{tabular}

$\mathrm{IHA}=$ Indirect haemagglutination; $\mathrm{SAPA}=S$. aureus protein A

anti-immunoglobulin (Coombs et al., 1953). Alternatively $S$. aureus bearing protein A can be used because this protein will bind IgG and subsequently agglutinate antigen-sensitised RBCs (Jagannath et al., 1984).

The results of this study show that use of $S$. aureus cells bearing protein A greatly enhances the sensitivity of the IHA test. Since the Wood 46 strain of $S$. aureus, which lacks protein $\mathrm{A}$ did not alter the sensitivity of the IHA and since $S$. aureus cells bearing protein $\mathrm{A}$ did not agglutinate sensitised DAS cells in the absence of antibody, co-haemagglutination appears to be mediated through protein $A$ and occurs only in the presence of specific antibody. The modified test showed greater sensitivity $(93.5 \%)$ than the unmodified IHA test $(80.6 \%)$ and much increased antibody titres in positive sera.
If the threshold of positivity is set at a titre of 128 , no false positives were observed among 45 normal sera; however, it is possible that such excellent discrimination may not extend to patients with liver disease other than that due to hydatid disease.

We did not compare the results of our modified test with those of ELISA in echinococcosis. However, earlier studies have shown that the sensitivity of protein A-mediated haemagglutination tests compares well with that of ELISA in the serological diagnosis of tuberculosis (Jagannath et al., 1984) and filariasis (Parija and Rao, unpublished data).

Reagents for the modified test are inexpensive, easily available and stable. The sensitised cells can be stored at $4^{\circ} \mathrm{C}$ for a long period with no loss of sensitivity (Jagannath and Sengupta, 1981 and Parija et al., 1986). Other studies have shown that prepared suspensions of $S$. aureus can be stored at $4^{\circ} \mathrm{C}$ or at room temperature for 8-12 weeks without loss of activity (Camargo et al., 1983). In contrast, the reagents for the ELISA test are expensive, difficult to obtain and perishable in tropical conditions.

The protein A-mediated haemagglutination test is simple, sensitive, inexpensive and does not require technical skill. The test deserves further evaluation in the serodiagnosis of echinococcosis.

\section{REFERENCES}

Arabatzis G, Papapanagiotou R 1963 Laboratory tests in hydatid disease: a comparison of the indirect haemagglutination, complement-fixation and intradermal tests. Bulletin of the World Health Organization 28:266-268.

Ardehali S, Kohanteb D J, Gerami S, Behfourouz N, Rezai H R, Vaez-Zadeh K 1977 Evaluation of counter immuno-electrophoresis, crossed electro-immunodiffusion and agar gel diffusion for immunodiagnosis of human hydatid disease. Transactions of the Royal Society of Tropical Medicine and Hygiene 71:481-485.

Bergquist N R, Waller T 1983 A novel simple immunoassay for rapid detection of human IgG antibodies to Toxoplasma gondii. Journal of Immunological Methods 61:339-344.

Camargo E P, Mattet D M, Yoshida N, Caulada Z 1983 Staphylococci adherence to trypanosomes exposed to immune sera as a method for the diagnosis of Chagas' disease. Transactions of the Royal Society of Tropical Medicine and Hygiene 77:825-827.

Chemtai A K, Bowry T R, Ahmad Z 1981 Evaluation of five immunodiagnostic techniques in echinococcosis patients. Bulletin of the World Health Organization 59:767-772.

Coombs R R A, Howard A N, Mynors LS 1953 A serological procedure theoretically capable of detecting incomplete or non-precipitating antibodies to soluble protein antigens. British Journal of Experimental Pathology 34:525-534.

Farshy DC, Kagan I G 1972 Use of stable sensitized cells in indirect microhemagglutination test for malaria. American Journal of Tropical Medicine and Hygiene 21:868-872. 
lacona A, Pini C, Vicari G 1980 Enzyme-Linked immunosorbent assay (ELISA) in the serodiagnosis of hydatid disease. American Journal of Tropical Medicine and Hygiene 29:95 102.

Jagannath C, Sengupta D N 1981 Serology of leprosy. I. Indirect haemagglutination test with stabilised sensitised red cells. Leprosy in India 53:507-512.

Jagannath C, Sengupta D N, Kasinathan S 1984 Staphylococcus aureus protein $\mathrm{A}$ antibody-mediated haemagglutination assay. A study on the interaction between protein A-bound specific antibodies and red cell bound specific antigens. International Archives of Allergy and Applied Immunology 73:296-302.

Kelkar S, Kotwal S E 1975 Counterimmunoelectrophoresis in diagnosis of hydatid disease Lancet i: 755-756.

Kronvall G 1973 A rapid slide-agglutination method for typing pneumococci by means of specific antibody adsorbed to protein A-containing staphylococci Journal of Medical Microbiology 6: 187-190.

Langone J J 1982 Use of labeled protein A in quantitative immunochemical analysis of antigens and antibodies. Journal of Immunological Methods 51:3-22.

Lewis J W, Koss N, Kerstein M D 1975 A review of echinococcal disease. Annals of Surgery 181:390-396.

Mansueto S, Migneco G, Tripi S, Picone D M 1980 Simplified counter-immuno-electrophoresis (CIEP) with a commercially produced antigen on cellulose acetate membrane for the diagnosis of hydatidosis. Transactions of the Royal Society of Tropical Medicine and Hygiene 74:260-261.

Ouchterlony Ö 1958 Diffusion-in-gel methods for immunological analysis. Progress in Allergy 5:1-78.

Parija S C, Ananthakrishnan N 1985 Evaluation of stabilised cells in the Indirect haemagglutination test for echinococcosis. Journal of Medical Microbiology 19, 95-98.

Parija S C, Mishra S R, Rao Sambasiva R 1986 Sensitised chick cells in IHA for echinococcosis. Journal of Medical Microbiology 22:243-245.

Parija S C, Rao R S, Badrinath S, Sengupta D N 1983 Hydatid disease in Pondicherry. Journal of Tropical Medicine and Hygiene 86: 113-115.

Schantz P M, Pappas M G, Cannon L T, Wahlquist S P 1984 Development of the Dot-ELISA for serodiagnosis of hydatid disease. Federation Proceedings 43: 1515.

Sivadasan K, Kurien B, John T J 1984 Rapid diagnosis of typhoid fever by antigen detection. Lancet $\mathrm{i}: 134-135$.

Stavitsky A B 1954 Micromethods for the study of proteins and antibodies. I. Procedure and general applications of hemagglutination and hemagglutination-inhibition reactions with tannic acid and protein-treated red blood cells. Journal of Immunology 72:360-367.

Varela-Diaz V M, Coltori E A 1974 Téchnicas para el diagnóstico immunológica de la hidatidosis humana. Centro Panamericano de Zoonosis, Series de Monografias Científicas y Technicas C.P.Z. No. 7, Buenos Aires. 